\title{
Pengaruh Motivasi terhadap Produktivitas Karyawan PT Telkom Indonesia, Tbk Cabang Palembang
}

\author{
Wendy Liana ${ }^{1)}$ \\ 1) Akademi Sekretari dan Manajemen Sriwijaya \\ Email: wendy_liana80@yahoo.com ${ }^{\text {l) }}$
}

\begin{abstract}
Abstrak
Tanpa motivasi seseorang tidak dapat melaksanakan tugasnya sesuai standar atau bahkan melampaui standar karena apa yang menjadi motif dan motivasinya dalam bekerja tidak dipenuhi. Untuk dapat menumbuhkan motivasi ini merupakan tugas penting bagi manajemen agar karyawan memiliki kemampuan tinggi dalam melaksanakan yang terbaik dari kemampuan mereka. Oleh karena itu seorang pemimpin harus bisa menjalankan perannya untuk membangkitkan semangat kepada para karyawannya. Motivasi kerja yang diberikan ini tentunya akan berpengaruh pada peningkatan produktivitas karyawan. Motivasi berkaitan erat dengan produktivitas kerja, karena semakin tinggi tingkat motivasi maka seseorang akan bersemangat melakukan pekerjaan sehingga penyelesaian pekerjaan menjadi lebih cepat dengan kualitas yang mengikuti standar yang ditetapkan. Suatu perusahaan dalam melaksanakan kegiatan, baik perusahaan yang bergerak di bidang industri perdagangan maupun jasa akan berusaha untuk mencapai tujuan yang telah ditetapkan sebelumnya, suatu hal yang penting yaitu bahwa keberhasilan berbagai aktivitas di dalam perusahaan dalam mencapai tujuan bukan hanya tergantung pada keunggulan teknologi, dana operasi yang tersedia, sarana ataupun prasarana yang di miliki melainkan juga tergantung pada aspek sumber daya manusia Faktor sumber daya manusia ini merupakan elemen yang harus diperhatikan oleh perusahaan terutama bila mengingat bahwa era perdagangan bebas segera dimulai di saat iklim kompetisi yang dihadapi akan sangat berbeda. Hal ini memaksa setiap perusahaan untuk dapat bekerja lebih efesien, efektif dan produktif.
\end{abstract}

Keywords: motivasi, produktivitas kerja

\section{Pendahuluan}

Motivasi adalah tindakan manajemen untuk mendorong karyawannya meningkatkan karir pada suatu perusahaan dengan suatu prestasi. Motivasi diberikan dalam bentuk imbalan berupa material dan non material, imbalan material yang pantas atas beban kerja pada suatu posisi akan mendorong karyawan menempati posisi itu. Orang akan lebih cenderung memilih posisi yang lebih rendah dengan imbalan material yang lebih tinggi pada perusahaan lain disbanding posisi yang lebih tinggi tetapi imbalan material yang lebih rendah pada perusahaan. Imbalan non material seperti reward (penghargaan) dan kompensasi tidak langsung dalam bentuk pengembangan kemampuan juga akan mendorong karyawan untuk berprestasi dan berkarir (Kartini Kartono, 2010, p. 1350).

Motivasi berkaitan erat dengan produktivitas kerja, karena semakin tinggi tingkat motivasi maka seseorang akan bersemangat melakukan pekerjaan sehingga penyelesaian pekerjaan menjadi lebih cepat dengan kualitas yang mengikuti standar yang ditetapkan. Suatu perusahaan dalam melaksanakan kegiatan, baik perusahaan yang bergerak di bidang industri perdagangan maupun jasa akan berusaha untuk mencapai tujuan yang telah ditetapkan sebelumnya, suatu hal yang penting yaitu bahwa keberhasilan berbagai aktivitas di dalam perusahaan dalam mencapai tujuan bukan hanya tergantung pada keunggulan teknologi, dana operasi yang tersedia, sarana ataupun prasarana yang di miliki melainkan juga tergantung 
pada aspek sumber daya manusia Faktor sumber daya manusia ini merupakan elemen yang harus diperhatikan oleh perusahaan terutama bila mengingat bahwa era perdagangan bebas segera dimulai di saat iklim kompetisi yang dihadapi akan sangat berbeda. Hal ini memaksa setiap perusahaan untuk dapat bekerja lebih efesien, efektif dan produktif. Tingkat kompetisi yang tinggi akan memacu tiap perusahaan untuk dapat mempertahankan kelangsungan hidup dengan memberikan perhatian pada aspek sumber daya manusia yang merupakan modal yang paling penting untuk mencapai tujuan perusahan, kunci kesuksesan sebuah perusahaan bukan hanya pada teknologi dan ketersedianya dana saja, faktor manusia dalam suatu perusahaan memegang peranan yang sangat penting, tenaga kerja memiliki potensi yang besar untuk menjalankan aktivitas perusahaan.

Sumber daya manusia merupakan modal yang paling penting untuk mencapai tujuan perusahan, kunci kesuksesan sebuah perusahaan bukan hanya pada teknologi dan ketersedianya dana saja, faktor manusia dalam suatu perusahaan memegang peranan yang sangat penting, tenaga kerja memiliki potensi yang besar untuk menjalankan aktivitas perusahaan. Perusahaan dan karyawan merupakan 2 (dua) hal yang saling membutuhkan jika karyawan berhasil membawa kemajuan bagi perusahaan, keuntungan yang diperoleh akan dipetik oleh kedua belah pihak. Bagi karyawan keberhasilan merupakan aktualitas potensi diri sekaligus peluang untuk memenuhi tujuan perusahaan, seperti mitra kerja yang diadakan PT Telkom Indonesia, Tbk Cabang Palembang dengan membuat kerjasama dengan PT Ovis Internasional dalam menerbitkan comunity "priority care" yang ditujukan kepada para pelanggan PT Telkom Indonesia, Tbk Cabang Palembang. Layanan khusus yang meliputi layanan pasang baru telepon, gangguan pengaduan, buka isolir dan pengaduan tagihan. Dari kerja sama identitas dapat kita lihat karyawan akan bekerja lebih maksimal untuk bisa menjalankan kerjasama ini serta bisa melayani pelanggan dengan baik, maka dari itu motivasi dalam kegiatan ini sangat berpengaruh untuk memaksimalkan kinerja karyawan PT Telkom Indonesia, Tbk Cabang Palembang. Untuk mendapatkan sumber daya manusia yang diharapkan oleh organisasi agar memberikan andil positif dalam semua kegiatan perusahaan untuk mencapai tujuannya.

Motivasi Kerja adalah keseluruhan proses pemberian motivasi bekerja kepada bawahan sehingga mereka mau bekerja tanpa paksaan demi tercapainya tujuan suatu organisasi dengan efisien dan ekonomis. Dengan adanya pemberian motivasi kerja kepada karywan memungkinkan perusahaan dapat mencapai produktivitas yang diharapkan karena para karyawannya termotivasi untuk lebih giat bekerja, berkarya, memberikan seluruh kemampuannya, pengetahuan dan keterampilan yang mereka miliki. Tanpa motivasi seorang tidak dapat melaksanakan tugasnya sesuai standar atau bahkan melampaui standar karena apa yang menjadi motif dan motivasinya dalam bekerja tidak dipenuhi (W.A. Gerungan, 2010, p.140).

Terkait mengenai motivasi Reskar R, 2001 dalam Hasibuan (1995, p. 161), melakukan penelitian dan mendapatkan hasil positif mengenai pengaruh motivasi terhadap produktivitas pada saat motivasi diri sendiri faktor yang memotivasi motivator yang paling pada diri sendiri adalah belief yaitu keyakinan bahwa diri bertanggung jawab pada tindakan dan prilaku sendiri.

Teori Motivasi Klasik yang diungkapkan Frederick Winslow Taylor dalam Hasibuan (2005, p. 105) menyatakan bahwa pekerja hanya termotivasi semata mata karena uang konsep ini menyatakan bahwa seorang akan menurun semangat kerjanya bila upah yang diterima dirasa 
terlalu sedikit atau tidak sebanding dengan pekerja yang harus dilakukan untuk memotivasi orang lain kita dapat memberi penghargaan menciptakan pekerjaan yang lebih baik, menjadi pendengar yang baik memberi tantangan, serta menolong tapi tidak melakukan sesuatu bagi orang lain yang sebenarnya dapat dilakukan oleh diri sendri salah satu yang dilakukan Manajer untuk memotivasi bawahannya adalah dengan memberi reward dapat dilakukan secara maksimal Manajer perlu menghormati keberagaman dan per individu, secara jelas memahami apa yang orang lain inginkan dari suatu pekerjaan dan mengalokasikan reward untuk memuaskan kebutuhan individu dan organisasi.

Kemampuan manajemen dalam memberikan motivasi akan sangat menentukan keberhasilan atau kegagalan dalam pencapaian tujuan perusahaan, maka PT Telkom Indonesia, Tbk Cabang Palembang dengan segala keterbatasan yang dimiliki mencoba untuk melaksanakan program tersebut. Keadaan demikian yang melatar belakangi penulisan penelitian ini yang berjudul: Bagaimana pengaruh motivasi terhadap produktivitas kerja karyawan pada PT Telkom Indonesia, Tbk Cabang Palembang?

\section{Tinjauan Pustaka}

\subsection{Produktivitas Kerja Karyawan}

Konsep produktivitas kerja dapat dilihat dari 2 (dua) dimensi, yaitu dimensi individu dan dimensi organisasi. Menurut Sugeng Budiono (2003, p. 4) produktivitas mempunyai beberapa pengertian yaitu:

1. Pengertian fisiologis, produktivitas yang mengandung arti sebuah sikap mental yang selalu mempunyai pandangan bahwa mutu kehidupan hari ini harus lebih baik dari hari sebelumnya.

2. Produktivitas merupakan perbandingan antara keluaran (output) dan masukan (input).

\subsection{Faktor-Faktor yang Mempengaruhi Produktivitas Kerja}

Ada banyak faktor yang dapat mempengaruhi tinggi rendahnya produktivitas kerja seorang karyawan. Menurut Handoko (2011, p. 135) bahwa faktor-faktor yang mempengaruhi produktivitas kerja adalah:

1. Pendidikan. Pada umumnya seseorang yang mempunyai pendidikan yang lebih tinggi akan mempunyai produktivitas kerja yang lebih baik. Dengan demikian pendidikan merupakan syarat yang penting dalam meningkatkan peroduktivitas karyawan. Tanpa bekal pendidikan mustahil orang akan mudah dalam mepelajari hal-hal yang bersifat baru.

2. Motivasi. Motivasi merupakan kekuatan atau motor pendorong kegiatan seseorang ke arah tujuan tertentu dan melibatkan segala kemampuan yang dimiliki untuk mencapainya. Dengan mengetahui motivasi itu, maka pimpinan dapat membimbing dan mendorong karyawannya untuk bekerja lebih baik.

3. Disiplin Kerja. Disiplin adalah sikap mental yang tercermin dalam tingkah laku perorangan, kelompok atau masyarakat berupa kepatuhan atau ketaatan terhadap peraturan, ketentuan, etika, norma yang telah ditentukan. Disiplin kerja mempunyai hunbungan erat dengan motivasi. Kedipsilinan dapat dibina melalui latihan-latihan, antara lain dengan bekerja menghargai waktu dan biaya yang akan memberikan pengaruh positif terhadap produktivitas karyawan. 
4. Keterampilan. Keterampilan banyak pengaruhnya terhadap produktivitaskerja karyawan. Keterampilan Kerja karyawan dalam perusahaan dapat ditingkatkan melalui kursuskursus atau latihan kerja.

5. Sikap dan etika kerja. Sikap seseorang atau kelompok orang dalam membina hubungan yang serasi, selaras dan seimbang di dalam kelompok itu sendiri maupun dengan kelompok lain dan etika dalam hubungan kerja sangat penting artinya, dengan tercapainya hubungan dalam proses produksi akan meningkatkan produktivitas.

6. Gizi dan kesehatan. Daya tahan tubuh seseorang biasanya dipengaruhi oleh gizi dan makanannya yang dikonsumsi setiap hari. Gizi yang baik akan mempengaruhi kesehatan karyawan dan semua itu akan mempengaruhi produktivitas karyawan.

7. Tingkat penghasilan. Semakin tinggi prestasi kerja karyawan maka akan semakin besar upah yang diterima. Dengan penghasilan yang cukup akan memberikan kepuasan terhadap karyawan tersebut dan bersemangat dalam bekerja.

8. Lingkungan kerja dan iklim kerja. Lingkungan kerja dari karyawan termasuk hubungan antar karyawan, hubungan dengan pimpinan, lingkungan kerja, penerangan dan lain-lain. Hal ini sangat penting untuk mendapatkan perhatian perusahaan karena karyawan enggan bekerja karena tidak ada kekompakan kerja atau ruangan kerja yang tidak menyenangkan, hal ini dapat mengganggu kerja karyawan.

9. Teknologi. Adanya kemajuan teknologi meliputi peralatan yang semakin otomatis dan canggih yang dapat mendudkung tingkat produksi dan mempermudah manusia melaksanakan pekerjaan.

10. Sarana produksi. Faktor-faktor produksi harus memadai dan saling mendukung dalam proses produksi. Mutu dan sarana produksi sangat berpengaruh terhadap peningkatan produktivitas.

11. Jaminan sosial. Perhatian dan pelayanan perusahaan kepada setiap karyawan menunjang kesehatan dan pelayanan keselamatan, dengan harapan supaya karyawan semakin bergairah dan mempunyai semangat kerja. Apabila jaminan sosial karyawan mencukupi maka akan dapat menimbulkan kesenangan bekerja, sehingga mendorong pemanfaatan kemampuan yang dimiliki untuk meningkatkan produktivitas kerja.

12. Manajemen. Adanya manajemen yang baik, maka karyawan akan terorganisasi dengan baik pula, sehingga produktivitas kerja maksimum.

13. Kesempatan berprestasi. Karyawan yang bekerja tentu mengharapkan peningkatan karir atau pengembangan potensi pribadi yang nantinya akan bermanfaat baik bagi ditrinya maupun organisasi. Setiap orang dapat mengembangkan potensi yang ada dalam dirinya, dengan diberikan kesempatan berprestasi maka akan karyawan akan meningkatkan produktivitasnya.

\subsection{Kerangka Pemikiran}

Berdasarkan uraian di atas dapat diketahui hubungan antara motivasi dengan produktivitas kerja seperti pada gambar berikut: 


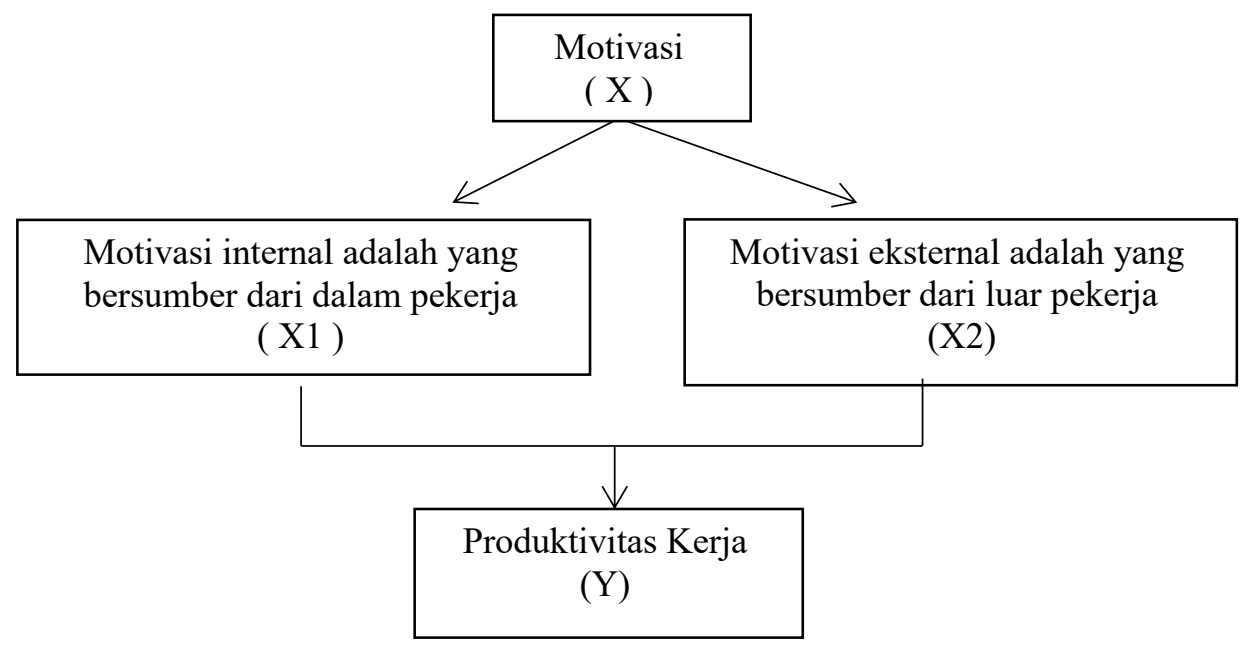

Dari kerangka pemikiran di atas dapat dijelaskan bahwa yang menjadi variabel independen (variabel bebas) adalah motivasi (X) (variabel terikat), yang terbagi menjadi X1 (motivasi internal) dan X2 (motivasi eksternal) dan yang menjadi variabel dependen adalah produktivitas kerja (Y).

\subsection{Hipotesis}

Dari rumusan masalah dan kerangka pemikiran maka dapat dibuat hipotesis sebagai berikut:

1. H1, diduga motivasi berpengaruh terhadap produktivitas kerja karyawan pada PT Telkom Indonesia, Tbk Cabang Palembang.

2. H2, diduga motivasi internal dan eksternal berpengaruh terhadap produktivitas kerja karyawan pada PT Telkom Indonesia, Tbk Cabang Palembang.

3. H3, diduga motivasi internal dan eksternal berpengaruh terhadap produktivitas kerja karyawan pada PT Telkom Indonesia, Tbk Cabang Palembang.

\section{Metode}

\subsection{Ruang Lingkup Penelitian}

Penelitian ini membahas masalah yang berkaitan dengan pengaruh motivasi terhadap produktivitas kerja karyawan pada PT Telkom Indonesia, Tbk Cabang Palembang. Dengan penelitian ini apakah pengaruh motivasi terhadap produktivitas karyawan berpengaruh secara signifikan.

\subsection{Populasi dan Sampel}

Jumlah responden dalam penelitian ini sebanyak 70 orang responden sesuai dengan jumlah populasi sekaligus sampel karyawan pada PT Telkom Indonesia, Tbk Cabang Palembang. Bila populasi besar penelitian tidak mungkin mengambil semua untuk penelitian maka penelitian dapat menggunakan sampel yang diambil dari populasi. 


\subsection{Definisi Pengukuran Variabel}

Dalam penelitian pada PT Telkom Indonesia, Tbk Indonesia Cabang Palembang, maka peneliti menyajian beberapa data primer yang dibuat sebagai wujud interprestasi dan penyerahan data dari hasil kuesioner yang telah disebarkan di PT Telkom Indonesia, Tbk Cabang Palembang.

1. Motivasi Internal (X1)

Motivasi internal adalah motivasi yang berasal dari dalam diri seseorang. Efek motivasi terhadap kinerja karyawan akan terciptanya jika motivasi internal ini sudah ada. Motivasi internal berperan penting dalam menciptakan prestasi yang tinggi dan terus menerus.

2. Motivasi Eksternal (X2)

Motivasi eksternal menjelaskan kekuatan yang ada di dalam individu yang dipengaruhi oleh faktor internal yang dikendalikan oleh Manajer, yaitu meliputi penghargaan, kenaikan panggang dan tanggung jawab. Manajer perlu mengenal motivasi eksternal untuk mendapatkan tanggapan yang positif dari karyawannya. Tanggapan yang positif ini menunjukkan bahwa bawahan sedang bekerja untuk kemajuan perusahaan.

3. Produktivitas Kerja Karyawan (Y)

Produktivitas kerja (tenaga kerja) adalah perbandingan antara hasil yang yang dicapai dengan peran serta tenaga kerja persatuan waktu, atau sejumlah barang/ jasa yang dapat dihasilkan oleh seseorang atau kelompok orang/ karyawan dalam jangka waktu tertentu. Produktivitas kerja dalam penelitian ini merupakan indikator yang sangat penting, dengan adanya produktivitas kerja diharapkan pekerjaan akan terlaksana secara efisien dan efektif. Produktivitas dalam kaitannya dengan karakteristik-karakteristik kepribadian individu yang muncul dalam bentuk sikap mental dan mengandung makna keinginan dan upaya individu yang selalu berusaha untuk meningkatkan kualitas kehidupannya.

\subsection{Teknik Analisis Data}

Uji statistik yang digunakan adalah uhji statistik f-test dan uji statistic t-test. Uji validitas dan reabilitas instrument menggunakan program SPSS 17.0 statistik for windows dengan responden sebanyak 70 responden.

\section{Pembahasan}

Dalam penelitian ini dijelaskan bahwa motivasi berpengaruh terhadap produktivitas kerja karyawan, serta kedua variabel motivasi internal (X1) dan motivasi eksternal (X2) berhubungan postitif dan signifikan terhadap produktivitas kerja karyawan (Y), dan motivasi yang dominan mempengaruhi produktivitas kerja karyawan adalah motivasi eksternal. Menurut Reskar semakin termotivasi karyawan dalam melakukan pekerjaan maka produktivitas kerja karyawan tersebut tinggi, sebaliknya jika karyawan tidak termotivasi dalam suatu pekerjaan maka produktivitas kinerja karyawan rendah. Dari hasil penelitian di atas dapat dilihat pengaruh motivasi eksternal terhadap produktivitas kerja sangat tinggi dibanding motivasi internal.

Hubungan motivasi eksternal terhadap produksitas kerja sangat mempengaruhi peningkatan kerja karyawan sebanyak 52,2\%. Dalam penelitian ini motivasi eksternal yang paling mempengaruhi produktivitas kerja karyawan adalah komunikasi yang baik antara karyawan dan atasan, lingkungan kerja yang baik, dan atasan selalu memberikan pujian. Ketiga faktor utama itu yang dapat meningkatkan kinerja karyawan dalam menyelesaikan tugas. Sedangkan dari tugas tanggapan respon hubungan motivasi internal yang memberikan pengaruh terhadap 
produktvitas kerja adalah prestasi kerja yang dimiliki, kepuasan dalam menyelesikan tugas dan pekerjaan yang menarik.

Dalam teori Maslow pegawai PT Telkom Indonesia, Tbk Cabang Palembang sudah tidak termotivasi dengan gaji rupiah yang dikategorikan kebutuhan fisikologis, dan dikaitkan upah yang diterima pegawai PT Telkom Indonesia, Tbk Cabang Palembang sudah mencukupi untuk memenuhi akan rasa aman rasa sangat mempengaruhi produktivitas kerja kerja karyawan dan termotivasi untuk bekerja lebih giat lagi.

Selanjutnya kebutuhan penghargaan, dari hasil yang yang diperoleh karyawan PT Telkom Indonesia, Tbk Cabang Palembang ternyata sangat membutuhkan penghargaan dari atasan sebagai motivasi mereka dalam mencapai produktivitas, hal ini bisa dilihat dari rata-rata tanggapan respon mengenai atasan.

Berdasarkan hasil uji determinasi $r$ square didapatkan hasil 0,477 , artinya motivasi eksternal dan internal secara bersama sama mempengaruhi kinerja karyawan sebesar $77,7 \%$ sisanya dipengaruhi oleh faktor lain di luar penelitian ini. Hal ini sekaligus menjawab permasalahan yang ada mengenai hubungan motivasi eksternal dan internal terhadap kinerja karyawan. Berdasarkan hasil uji registrasi linier didapatkan unstandaried coefficent $\mathrm{b}$ dari dari motivasi eksternal 0,522, lebih besar dibanding motivasi eksternal sebesar 0,322 artinya bahwa $52,25 \%$ kinerja karyawan dipengaruhi oleh motivasi eksternal lebih dominan dalam meningkatkan produktivitas kerja karyawan indikator dari eksternal tersebut antara lain di karenakan kondisi kerja dan jaminan finansial dan sosial yang baik (Augustine dan Kristaung, 2013, p. 70).

\subsection{Uji Hipotesis (uji f)}

Uji f digunakan untuk mengukur seberapa jauh pengaruh variable bebas secara bersama-sama dalam menerangkan variasi variabel terikat. Jika signifikan $\mathrm{f}>0,05$ maka dapat dinyatakan bahwa variabel bebas secara simultan berpengaruh signifikan terhadap variabel terikat.

\subsection{Uji Hipotesis (uji t)}

Uji statistic $\mathrm{t}$ digunakan untuk mengukur seberapa jauh pengaruh variabel bebas secara individu dalam menerangkan variasi variable terikat. Jika nilai t-hitung lebih besar dari nilai ttabel, maka dapat dinyatakan bahwa variabel bebas secara individual berpengaruh positif terhadap variabel terikat. Jika signifikan $t>0,05$ maka dapat dinyatakan bahwa variabel bebas secara individual berpengaruh signifikan terhadap variabel terikat.

\section{Kesimpulan}

Berdasarkan hasil penelitian dan pembahasan, maka kesimpulan yang dapat diambil adalah sebagai berikut:

1. Hasil pengujian analisis regresi linier berganda bahwa motivasi berpengaruh secara signifikan terhadap produktivitas kerja karyawan pada PT Telkom Indonesia, Tbk Cabang Palembang.

2. Motivasi internal dan motivasi eksternal berpengaruh terhadap produktivitas kerja karyawan pada PT Telkom Indonesia, Tbk Cabang Palembang.

3. Diperoleh hasil bahwa variabel yang paling dominan adalah motivasi eksternal (X2), bahwa kondisi kerja, atasan yang baik, jaminan finansial dan sosial memberikan pengaruh terhadap produktivitas kerja pada perusahaan sedangkan analisis yang diperoleh dari dari motivasi internal bahwa pekerjaan yang menyenangkan, pekerjaan yang mempunyai 
tantangan, dan pekerjaan yang menarik memberikan pengaruh terhadap produktivitas dengan demikian hipotesis yang diajukan terbukti.

\section{Referensi}

A.M. Sugeng Budiono (2003). Bunga Rampai Hiperkes dan Keselamatan Kerja. Semarang: Badan Penerbit UNDIP.

Augustine, Y dan R. Kristaung (2013). Metodologi Penelitian Bisnis dan Akuntansi. Jakarta: PT Dian Rakyat.

Handoko, T. Tani (2011). Manajemen Personalia dan Sumber Daya Manusia. Yogyakarta: Edisi Kedua, Cetakan Kesebelas: BPFE.

Hasibuan, Malayu S.P (1995). Manajemen Sumber Daya Manusia: Dasar dan Kunci. Jakarta: Toko Gunung Agung.

Hasibuan, Malayu S.P (2005). Manajemen Sumber Daya Manusia. Edisi Revisi. Jakarta: Bumi Aksara.

Kartono, Kartini Dr (2010). Pemimpin dan Kepemimpinan. Jakarta: PT Raja Grafindo Perkasa.

W.A. Gerungan Dr (2010). Psikologi Sosial. Bandung: PT Refika Aditama. 